\title{
Diel Investments in Phytoplankton Metabolite Production Influenced by
}

\section{Associated Heterotrophic Bacteria}

$10{ }^{1}$ Department of Marine Sciences, University of Georgia, Athens, GA, 30602, US

$11{ }^{2}$ Complex Carbohydrate Research Center, University of Georgia, Athens, GA, 30602, US

12

13

14 Running Head: Phytoplankton Metabolite Production Influenced by Associated Bacteria

15

$16{ }^{*}$ Corresponding Author: Mary Ann Moran, Department of Marine Sciences, University of Georgia, Athens,

17 GA 30602-3636, US, mmoran@uga.edu, 706-542-6481 


\section{Abstract}

Organic carbon transfer between photoautotrophic and heterotrophic microbes in the surface ocean mediated through metabolites dissolved in seawater is a central but poorly understood process in the global carbon cycle. In a synthetic microbial community in which diatom extracellular release of organic molecules sustained growth of a co-cultured bacterium, metabolite transfer was assessed over two diel cycles based on per cell quantification of phytoplankton endometabolites and bacterial transcripts. Of 31 phytoplankton endometabolites identified and classified into temporal abundance patterns, eight could be matched to patterns of bacterial transcripts mediating their uptake and catabolism. A model simulating the coupled endometabolite-transcription relationships hypothesized that one category of outcomes required an increase in phytoplankton metabolite synthesis in response to the presence of the bacterium. An experimental test of this hypothesis confirmed higher endometabolome accumulation in the presence of bacteria for all five compounds assigned to this category - leucine, glycerol-3-phosphate, glucose, and the organic sulfur compounds dihydroxypropanesulfonate and dimethylsulfoniopropionate. Partitioning of photosynthate into rapidly-cycling dissolved organic molecules at the expense of phytoplankton biomass production has implications for carbon sequestration in the deep ocean. That heterotrophic bacteria can impact this partitioning suggests a previously unrecognized influence on the ocean's carbon reservoirs.

\section{Significance Statement}

Microbes living in the surface ocean are critical players in the global carbon cycle, carrying out a particularly key role in the flux of carbon between the ocean and atmosphere. The release of metabolites by marine phytoplankton and their uptake by heterotrophic bacteria is one of the major 
bioRxiv preprint doi: https://doi.org/10.1101/2020.11.18.388827; this version posted November 20, 2020. The copyright holder for this preprint (which was not certified by peer review) is the author/funder, who has granted bioRxiv a license to display the preprint in perpetuity. It is made available under aCC-BY-ND 4.0 International license.

41 routes of microbial carbon turnover. Yet the identity of these metabolites, their concentration in

42 seawater, and the factors that affect their synthesis and release are poorly known. Here we provide

43 experimental evidence that marine heterotrophic bacteria can affect phytoplankton production and

44 extracellular release of metabolites. This microbial interaction has relevance for the partitioning of

45 photosynthate between dissolved and particulate carbon reservoirs in the ocean, an important

46 factor in oceanic carbon sequestration. 


\section{Introduction}

48 Photoautotroph-heterotroph metabolite transfer in the surface ocean is a key process in global

49 carbon cycling through which up to half of fixed carbon is transferred to bacteria in the form of

50 labile dissolved compounds ${ }^{1}$. Phytoplankton synthesis and release of metabolites exhibit diel cycles,

51 synchronized with the availability of light energy ${ }^{2-4}$. The observation of similar diel activity cycles in

52 co-occurring heterotrophic bacteria suggests a tight temporal linkage controlled by the timing of

53 phytoplankton extracellular release $e^{5,6}$. Though the importance of the trophic link between marine

54 phytoplankton and bacteria in the global carbon cycle has long been recognized ${ }^{7-9}$, identifying the

55 metabolites responsible and measuring their flux is challenging. These compounds have short

56 turnover times in seawater due to rapid uptake by bacteria, have shared physical properties with

57 salt, and are maintained at low, typically $\mathrm{nmol} \mathrm{L}^{-1}$ to $\mathrm{pmol} \mathrm{L}^{-1}$, concentrations ${ }^{10,11}$.

58 Intracellular phytoplankton metabolite pools (endometabolites) are the presumptive substrates

59 for heterotrophic bacteria, yet how faithfully phytoplankton internal concentrations predict

60 exometabolite availability depends on the mechanism of release, of which several have been

61 recognized ${ }^{12,13}$. In the simplest mechanism, differences in metabolite concentration between

62 phytoplankton intracellular pools and ambient seawater can drive diffusion ${ }^{14}$ (i.e., passive diffusion

63 mechanism), in which case substrate supply to heterotrophic bacteria is largely controlled by

64 endometabolite concentrations. Alternatively, active excretion of metabolites to maintain cellular

65 balance can occur by overflow pathways ${ }^{15}$, for example to manage redox state or products of

66 photorespiration (i.e., physiological balance mechanism). Finally, metabolites may be synthesized

67 and excreted in response to associated microbes, for example to sustain mutualisms or mount

68 defenses $^{16,17}$ (i.e., interaction response mechanism). 
Here we determined the correspondence between phytoplankton intracellular pools and

70 heterotrophic bacterial substrate availability by examining diel patterns of endometabolomes and

71 transcriptomes. A synthetic community was established in which marine diatom Thalassiosira

72 pseudonana CCMP $1335^{18}$ was the only source of substrates to bacterium Ruegeria pomeroyi DSS- $3^{19}$.

73 As diatoms contribute up to $40 \%$ of primary production in the surface ocean ${ }^{20}$ and $R$. pomeroyi

74 belongs to a taxon that dominates diatom bloom communities ${ }^{21,22}$, this simple community

75 represents a key phytoplankton-bacteria link in the surface ocean. Over two day-night cycles, we

76 contemporaneously assayed phytoplankton endometabolite pools by nuclear magnetic resonance

77 (NMR) spectroscopy and bacterial metabolite consumption using transcriptome proxies and

78 assessed links between the two. Transcript abundance was analyzed as the number of mRNA

79 molecules per bacterial cell, enabled by the use of internal mRNA standards; this approach yields

80 the absolute number of transcripts harbored by a cell for a given gene, matching absolute

81 quantitation in the metabolite data and eliminating ambiguities inherent in proportional expression

82 data ${ }^{23,24}$. The quantitative chemical-biological analytical framework applied to this synthetic

83 community enabled us to assess mechanisms underlying temporal links between microbial

84 autotrophs and heterotroph in the production and consumption of labile metabolites.

Results and Discussion

$8816 \mathrm{~h}: 8 \mathrm{~h}$ light:dark cycle, with maximum at noon. After $6 \mathrm{~d}, R$. pomeroyi was inoculated into the

89 cultures, and a 2-day pre-incubation followed to allow the bacteria to assimilate labile metabolites

90 that accumulated during the axenic phase. Beginning on day 8 , samples were collected every $6 \mathrm{~h}$ for

91 the next $48 \mathrm{~h}$ at timepoints corresponding to midnight, mid-morning, noon, and mid-afternoon. 
93 during the $48 \mathrm{~h}$ sampling window revealed 282 major peaks absent in the blank spectrum.

94 Annotation by comparison to metabolomic databases and chemical standards suggested by previous

95 studies ${ }^{25,26}$ resulted in 31 compounds (156 peaks) identified with high confidence (Table 1; see Table

96 S1 and Fig. S1 for detailed annotation and confidence level information). The number of diatom cells

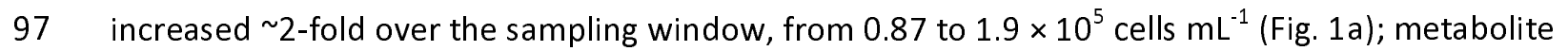

98 data were normalized to cell number at the time of sampling.

To group metabolite peaks that behaved similarly over the diel cycles, cell-normalized absolute abundance data were clustered by variance-sensitive clustering ${ }^{27}$ which identified four patterns (Fig. 1b and 1c; Table 1). Group M-1 consisted of metabolites for which monotonic increases in intensity dominated the $48 \mathrm{~h}$ sampling window. Twelve compounds annotated with high confidence from this cluster included amino acids (asparagine, glycine, isoleucine, leucine, and lysine), amino acid derivatives (glycine betaine and homarine), an amino alcohol (ethanolamine), a choline derivative (phosphorylcholine), a glycerol derivative (glycerol-3-phosphate), and the sulfur-containing compounds dihydroxypropanesulfonate (DHPS) and dimethylsulfoniopropionate (DMSP) (Table 1,

Fig. S2). Metabolite group M-2 was characterized by peaks for which decreases in concentrations over time was the dominant pattern, and included two organic acids (3-hydroxybutyrate, acetate) and one unidentified organic acid. The two other metabolite clusters exhibited diel concentration patterns that peaked in the light and declined in the dark (Table 1, Fig. S2). Group M-3 peaks reached their maximum intensities at mid-afternoon (RAIN, $p \leq 0.001$ ) and contained high-

112 confidence annotations of the nucleoside uridine and the carbohydrates glucose and $\beta$-1,3-glucan,

113 the latter a subunit of the major diatom polysaccharide laminarin ${ }^{28}$. Group M-4 peaks exhibited diel

114 patterns with maximum intensities at mid-morning or noon (RAIN, $p \leq 0.01$ ) and included high

115 confidence annotations for the amino acids aspartate, glutamine, and proline. Thus four distinct 
116 temporal patterns of endometabolite concentrations were observed for T. pseudonana cells co-

117 growing with a heterotrophic bacterium under a light regime mimicking that of the surface ocean

118 (Fig. 1b).

Bacterial transcription patterns - We next examined concurrent bacterial transcript inventories

120 indicative of metabolite consumption, normalized to cell counts at the time of sampling (Fig. 1a).

121 The total number of transcripts cell ${ }^{-1}$ varied significantly over the diel cycle (ANOVA; $n=26, p<0.01$ ),

122 with 2.5-fold more mRNAs in the mid-morning and noon cells ( $95 \pm 49$ and $114 \pm 53$ mRNAs cell ${ }^{-1}$ )

123 relative to mid-afternoon and night $\left(42 \pm 11\right.$ and $58 \pm 25$ mRNAs cell $\left.^{-1}\right)$. Correspondingly, the

124 majority of genes had higher transcripts per cell at mid-morning and noon relative to mid-afternoon

125 and night (Fig. S3). This transcript inventory is low compared to exponentially growing Escherichia

126 coli $\left(1,350\right.$ mRNAs cell ${ }^{-1}$; ref $\left.^{29}\right)$ but comparable to previous measures for marine bacteria in ocean

127 environments ${ }^{24}$

128 To identify genes that behaved similarly over time, the per cell transcript inventories for each of

129 the 4,278 protein-encoding genes in the R. pomeroyi genome were clustered by variance-sensitive

130 clustering (Fig. 1b and C). Among the genes encoding substrate transporters, the majority (87\%)

131 were classified into Group G-1 (3,294 total genes, 539 transporter genes), for which the

132 transcription pattern was a diel cycle with a maximum value at noon (Fig. 2). G-1 transporters

133 showing the largest diel shifts in expression encoded the uptake of sugars (e.g., ribose), amino acid

134 derivatives (ectoine and 5-hydroxyectoine), amines (trimethylamine, trimethylamine- $\mathrm{N}$-oxide, and

135 spermidine), an organic acid (glycolate), a purine (xanthine), phosphonates, and organic sulfur

136 compounds (DHPS, isethionate, cysteate, $\mathrm{N}$-acetyltaurine, choline- $\mathrm{O}$-sulfate, and DMSP); for these

137 compounds, bacteria expressed 13- to 58-fold more transcripts per cell at noon relative to night

138 (mean ratio: $33.5 \pm 11.7, n=50$ ) (Fig. 2). Transporters with less extreme diel swings in expression but

139 still biased toward noon encoded uptake of taurine, glucose, and sn-glycerol-3-phosphate, with 
140 noon-night expression ratios an order of magnitude lower (mean ratio: $3.3 \pm 1.3, n=11$ ). For these,

141 the dampened diel expression dynamics were due to high night transcript inventories rather than

142 low noon inventories (Fig. 2), suggesting their targets were among the more available substrates at

143 night. Group G-2, for which the temporal transcription pattern was similar to G-1 but with higher

144 values at the first night and mid-morning time points, contained $11 \%$ of transporter genes (756 total

145 genes, 68 transporter genes) (Fig. 1c). Group G-3, for which diel patterns were not dominant but,

146 similar to G-2, the first night and mid-morning values were high (Fig. 1C), contained $2 \%$ of

147 transporter genes (271 total genes, 10 transporter genes). Putrescine, glycine betaine/proline, and

148 choline transporter proteins were classified in G-2 or G-3. Higher transcript inventories at initial time

149 points could reflect incomplete bacterial drawdown of an accumulated metabolite during the pre-

150 incubation.

151 Bacterial transporter expression was also calculated as a percent of the total transcriptome (Fig.

152 S4), the prevailing analysis approach for RNAseq data ${ }^{30}$ when internal standards are not available.

153 Relative investment calculations categorized $51 \%$ of transporter genes as significantly enriched in

154 the noon transcriptome relative to night, compared to $81 \%$ significantly higher per cell transcript

155 inventories at noon relative to night for the internal standard-based approach (Fig. S4). These

156 analyses emphasize, on the one hand, the bacterium's investment in expression of a transporter

157 relative to other cellular functions, and on the other, the actual number of templates available for

158 synthesizing transporter proteins.

159 Diel oscillations in photosynthesis parameters - We noticed that R. pomeroyi produced many-

160 fold fewer transcripts for substrate acquisition in the mid-afternoon compared to mid-morning (Fig.

1612 2), despite the fact that illumination was identical. Indeed, $>75 \%$ of the bacterium's transporter

162 genes had transcript inventories that were statistically indistinguishable between mid-afternoon and

163 night (Fig. S3). Diel oscillations in the relationship between carbon fixation rate and irradiance have 
164 been broadly documented for marine phytoplankton in laboratory and field studies, characterized

165 by pre-noon maxima in photosynthesis rates ${ }^{31,32}$. Thus the rapid decrease in expression of most

166 bacterial transporters by mid-afternoon suggests that periodicity in carbon fixation-irradiance

167 relationships are manifested in phytoplankton extracellular release as well. One feature of diel

168 photosynthesis oscillation, the $\mathrm{E}_{\mathrm{k}}$-dependent variability in photosynthesis parameters, is

169 hypothesized to result from a metabolic shift by phytoplankton from pre-noon synthesis of amino

170 acid and lipids to post-noon synthesis of storage carbohydrates and nucleic acids ${ }^{33,34}$. The $T$.

171 pseudonana endometabolome concentrations were fully consistent with this hypothesis; high

172 confidence metabolites assigned to group M-4 (maximum concentrations at mid-morning or noon)

173 are proline, aspartate, and glutamine, and to group M-3 (maximum concentrations at mid-

174 afternoon) are glucose, $\beta(1,3)$-glucan storage molecules, and uridine (Fig. S2 and S5). Previously

175 observed offsets in diel timing of maximum transcription by distinct surface ocean bacterial taxa ${ }^{5}$

176 could thus reflect changes in the composition of phytoplankton extracellular release.

178 identified in the R. pomeroyi genome, we assessed whether light could be directly responsible for

179 changes in gene expression. The bacterium was inoculated into spent medium from axenic $T$.

180 pseudonana and exposed in triplicate to one of three light levels matching co-culture irradiance at

181 noon, mid-morning/mid-afternoon, and night for $4 \mathrm{~h}$. Only 61 genes in the bacterial culture $(1.4 \%$ of

182 the R. pomeroyi genome) were significantly enriched by one or both light levels (Fig. S6), indicating

183 that diel differential expression in the co-cultures was primarily mediated indirectly through

184 phytoplankton activities. One group of 10 light-enriched genes function in protection against

185 reactive oxygen species (ROS) (Fig. S7, Table S2), which can be formed when light interacts with

186 oxygen or organic compounds ${ }^{35-37}$. A second group of 16 enriched genes function in the uptake and

187 metabolism of phosphate (pstSCAB, phoU), and phosphonate (phnDEC, phnIGHLJN) (Fig. S7), and 
188 were likely under the control of the similarly enriched phoB regulatory protein ${ }^{38-40}$. Phosphorus

189 acquisition transcript enrichment was surprising, since phosphorus availability was identical at all

190 light levels, and phosphate concentrations remain non-limiting for many weeks in this synthetic

191 culture system $\left(>10 \mu \mathrm{mol} \mathrm{L}^{-1}\right)^{26}$. This raises the possibility of light-dependent stimulation of

192 phosphorus acquisition by bacteria that compete with phytoplankton for nutrients ${ }^{41}$, consistent with

193 temporal partitioning of nutrient uptake observed in ocean data ${ }^{42}$, and potentially triggered by

194 seawater ROS concentrations.

Coincidence of diatom metabolite accumulation and bacterial transcription - Eight metabolites

196 that were represented in the diatom endometabolome dataset had genes recognized to mediate

197 their uptake or catabolism in the bacterial transcriptome dataset (Table 2). For four of these (leucine,

198 glycerol-3-phosphate, DHPS, and DMSP), an increasing endometabolome concentration was paired

199 with a diel gene expression pattern (Figs. 3a, S8). One (proline) exhibited a noon peak in both

200 endometabolome concentration and gene expression; two (glucose and uridine) exhibited mid-

201 afternoon peaks in endometabolome concentration that lagged noon peaks in gene expression by 6

$202 \mathrm{~h}$; and one (acetate) exhibited a decreasing endometabolome concentration paired with diel gene

203 expression (Fig. 3a).

204 We asked whether the observed paired data patterns could occur under a null model of

205 changing phytoplankton exometabolite release following bacterial inoculation; that is, with no

206 mechanism for increased phytoplankton excretion in response to neighboring microbes. A

207 simulation model was used to compute phytoplankton exometabolite release using functions

208 representing two of the proposed mechanisms of extracellular release, passive diffusion and

209 physiological balance, but not the interaction response mechanism (Fig. 3d). To simulate

210 transcription, the model assumed that R. pomeroyi transporter systems are regulated by the

211 availability of their substrate, which has been supported in previous studies ${ }^{43-47}$. Thus bacterial 
212 transcript inventories were taken as the simulated exometabolite uptake rate, according to

213 Michaelis-Menten kinetics. The model successfully recapitulated three of the four experimental

214 patterns of paired metabolome concentration and transporter expression data (Fig. 3b left; Table

215 S3). The pattern that could not be generated with the base model was that of increasing

216 endometabolome concentrations ( $M-1$ ) paired with diel gene expression (G-1), which was observed

217 for leucine, glycerol-3-phosphate, DHPS, and DMSP (Fig. 3b left) (Pearson's $r=-0.41$ to -0.10 ).

218 However, addition of a phytoplankton interaction response mechanism that increased

219 endometabolite production rate upon bacterial inoculation enabled the model output to mimic the

220 M-1, G-1 pattern (Fig. 3b right). We noticed that output for glucose (M-3, G-1) insufficiently

221 captured the temporal trend of endometabolome concentration (Fig. 3b left; Table S3), and further

222 analysis identified a significant linear increase in glucose concentrations $(p \leq 0.001)$ embedded

223 within a significant diel pattern (RAIN, $p \leq 0.01$ ). Implementation of a phytoplankton interaction

224 response also improved simulation of the glucose data (Fig. 3b right).

The simulation modeling generated a hypothesis that diatoms accumulate higher concentrations

226 of certain endometabolites in the presence of heterotrophic bacteria. This was tested using an

227 available independent dataset in which T. pseudonana was grown in co-culture with bacteria $(R$.

228 pomeroyi and two other heterotrophic bacteria) for $15 \mathrm{~d}$, after which endometabolites were

229 compared with those in axenic controls. Consistent with model predictions, all five endometabolites

230 that increased in concentration in the diel study also had higher concentrations in co-culture

231 endometabolomes compared to axenic in the $15 \mathrm{~d}$ study (Fig. 3c). For the three metabolites that did

232 not increase in concentration during the diel study (acetate, uridine, and proline) there was no

233 difference in endometabolite concentrations in the $15 \mathrm{~d}$ study (Fig. 3c; see also Fig. S9 for other

234 compounds). How T. pseudonana might detect associated bacteria is not yet known, but could

235 involve signals released from the bacteria or by bacterial alteration of environmental conditions, 
236 such as nutrient pools. Previous research uncovered a phytoplankton-bacteria signaling system in

237 which a marine diatom (Pseudo-nitzchia multiseries) released tryptophan extracellularly, and a co-

238 cultured marine bacterium (Sulfitobacter sp. S11) converted it to the plant hormone indole-3-acetic

239 acid. In our model system, bacterium R. pomeroyi (a relative of Sulfitobacter sp. S11, both members

240 of the Roseobacter group) maintained 7- to 36-fold higher transcript inventories of IAA synthesis

241 genes at noon relative to night (Fig. 4a). Further, expression of these same IAA genes was positively

242 correlated with diatom biomass when R. pomeroyi was introduced at intervals into a natural

243 phytoplankton bloom ${ }^{48}$ (Fig. 4b). These suggest both that IAA may play a role in a T. pseudonana - $R$.

244 pomeroyi interaction, and that IAA signaling may broadly underlie marine diatom-bacteria

245 interactions in the surface ocean ${ }^{16}$. Our observation that concentrations increase only for certain

246 components of the diatom exometabolome is consistent with evolutionary tuning through selection.

247 A major fraction of the ocean's annual net primary production is processed through the labile

248 dissolved organic carbon pool, driven by the production, release, and consumption of microbial

249 metabolites ${ }^{9}$. In agreement with previous field observations of coincident diel patterns of

250 phytoplankton and bacterial activity ${ }^{5,42,49}$, we find coupling of phytoplankton endometabolite

251 dynamics with bacterial exometabolite uptake transcription in a model system representative of

252 diatom-dominated surface ocean ecosystems. The quantitative importance of marine

253 phytoplankton-bacteria carbon flux has motivated inquiries into the physical and chemical factors

254 that regulate phytoplankton extracellular release, such as light, temperature, and nutrient

255 limitation $^{33}$. This study suggests that heterotrophic bacteria also influence this process, with

256 implications for ocean carbon sequestration via allocation of photosynthate between dissolved and

257 particulate organic carbon reservoirs. 
Diel experiment - An axenic strain of marine diatom Thalassiosira pseudonana CCMP1335

261 was cultured at $18^{\circ} \mathrm{C}$ in three replicate $15-\mathrm{L}$ polycarbonate bottles containing $10 \mathrm{~L}$ of $\mathrm{L} 1$ medium $^{50}$ in

262 which $\mathrm{NaH}^{13} \mathrm{CO}_{3}$ (Cambridge Isotope Laboratories, $\mathrm{CLM}-441$ ) was used as the source of inorganic

263 carbon. The light cycle consisted of $16 \mathrm{~h}$ light, during which light intensity varied gradually between

2640 and $150 \mu \mathrm{mol}$ photon $\mathrm{m}^{-2} \mathrm{~s}^{-1}$ with a maximum intensity at noon, followed by $8 \mathrm{~h}$ of dark. Bacterial

265 strain Ruegeria pomeroyi DSS-3 was grown at $30^{\circ} \mathrm{C}$ on $1 / 2$ YTSS agar and transferred to $1 / 2$ YTSS liquid

266 medium for overnight growth. Axenic T. pseudonana cultures grown for 6 days were inoculated with

267 bacterial cells washed in L1 medium three times (final concentration, $10^{6}$ bacterial cells $\mathrm{mL}^{-1}$ ). Co-

268 cultures were pre-incubated for two days to allow time for accumulated labile phytoplankton

269 metabolites to be consumed by the bacteria and thus emphasize synchronized production and

270 consumption dynamics during diel cycles. After the pre-incubation period, samples were collected

271 every $6 \mathrm{~h}$ over the next $48 \mathrm{~h}$ for bacterial mRNA sequencing, phytoplankton and bacterial cell counts,

272 and phytoplankton endometabolome analysis.

Direct light effects experiment - T. pseudonana CCMP1335 was axenically cultured in $10 \mathrm{~L}$ of

274 L1 medium in a 15-L polycarbonate bottle with incubation conditions as described above except that

275 an intensity of $150 \mu \mathrm{mol}$ photon $\mathrm{m}^{-2} \mathrm{~s}^{-1}$ was used throughout the light period. After one week, the

276 diatom cultures were sequentially filtered through GF/F filters (Whatman) and 0.2- $\mu$ m-pore-size

277 PCTE membrane filters (Poretics), and the cell-free filtrate was used as the substrate for a bacterial

278 monoculture experiment. $R$. pomeroyi DSS-3 cells were prepared and added to the filtrate as

279 described above. Cells were incubated for $4 \mathrm{~h}$ at $18^{\circ} \mathrm{C}$ under light intensities of 150 (100\%

280 treatment), 75 (50\% treatment), or $0 \mu \mathrm{mol}$ photon $\mathrm{m}^{-2} \mathrm{~s}^{-1}(0 \%$ treatment), corresponding to light

281 levels at noon, mid-morning and mid-afternoon, and night in the diel experiment, with three

282 replicates of each treatment. A minor temperature increase of $0.5^{\circ} \mathrm{C}$ occurred in the $100 \%$ 

counts were collected. culture onto $2.0-\mu \mathrm{m}$-pore-size PCTE membrane filters (MilliporeSigma Isopore) and stored at $-80^{\circ} \mathrm{C}$ until processing. Endometabolites were extracted by sonication in ultra-pure water (Millipore), concentrated by freeze-drying, and dissolved in $600 \mu \mathrm{L}$ of sodium phosphate butter (pH 7.4) with an internal standard of 2,2-dimethyl-2-silapentane-5-sulfonate- $\mathrm{d}_{6}\left(1 \mathrm{mmol} \mathrm{L}^{-1}\right)^{51}$. Metabolites were analyzed by nuclear magnetic resonance (NMR) spectroscopy using a Bruker AVANCE III $800 \mathrm{MHz} 5$ $\mathrm{mm} \mathrm{TCl}$ cryoprobe, $800 \mathrm{MHz} 1.7 \mathrm{~mm} \mathrm{TCl}$ cryoprobe, and $600 \mathrm{MHz} 5 \mathrm{~mm}$ TXI probe. Pulse programs of ${ }^{1} \mathrm{H}-{ }^{13} \mathrm{C}$ heteronuclear single quantum correlation (HSQC; Bruker program hsqcetgpprsisp2.2), ${ }^{1} \mathrm{H}-$ multiple bound correlation (HMBC; hmbcetgpl2nd) were used. Data were processed using TopSpin 4.0.3 (Bruker), and peak intensity was extracted using rNMR 1.1.9 $9^{52}$. Metabolites were annotated based on chemical shift (HSQC) and coupling information (HSQC-TOCSY and HMBC). HMDB ${ }^{53}$ and $\mathrm{BMRB}^{54}$ were used as reference databases, and additionally $\mathrm{CSDB}^{55}$ for polysaccharides. Three compounds of interest which are not in these databases were annotated either by obtaining original

300 level of annotation ranging from 1 (lowest) to 5 (highest) was assigned to each metabolite (Table S1)

301 according to Walejko et $\mathrm{al}^{58}$ with a slight modification, where 1 = putative compounds with

302 functional group information; 2 = partially matched to HSQC chemical shift information in the 303 databases or literature; 3 = matched to HSQC chemical shift; 4 = matched to HSQC chemical shift 304 and validated by HSQC-TOCSY or HMBC; 5 = validated by original spectra from chemical standards. 305 Detailed parameter settings are presented in Table S4, with additional information in Metabolomics 306 Workbench (ID PR001019, dx.doi.org/10.21228/M80408). Temporal variations in metabolites were 
307 analyzed by extracting peaks behaving similarly during the incubation period using variance-

308 sensitive clustering ${ }^{27}$ after normalization by the internal standard and cell counts, and scaling to Z-

309 scores. Background signals originating from filters and solvent were also corrected. The optimal

310 cluster number was selected based on minimum centroid distance and Xie-Beni index, and only

311 membership values of $<0.5$ were accepted ${ }^{27}$. Periodicity of the temporal patterns for compounds was

312 analyzed using a rhythmicity analysis package RAIN (1.18.0) $)^{59}$ in R software (version 3.6.1).

313 Heatmaps were created using the CirHeatmap function (version 1.7) in MATLAB (Mathworks) ${ }^{60}$.

314 mRNA analysis - For the direct light experiment, bacterial cells were collected by filtering

$315500 \mathrm{~mL}$ of culture through 0.2- $\mu \mathrm{m}$ pore-size PES membrane filters (Pall Supor) and immediately

316 freezing the filters in liquid nitrogen. For the diel experiment, samples were pre-filtered through 2.0-

$317 \mu \mathrm{m}$-pore-size PCTE membrane filters (MilliporeSigma Isopore) to retain diatom cells prior to

318 capturing bacterial cells on $0.2-\mu \mathrm{m}$ pore-size filters. This process was completed within 15 min of

319 collection. The filters were stored at $-80^{\circ} \mathrm{C}$ until processing. To extract RNA, filters were cut into

320 pieces under sterile conditions and shaken with $0.5 \mathrm{~mL}$ of 0.1-mm zirconia/silica beads (BioSpec

321 Products) in $1 \mathrm{~mL}$ of Denaturation/Lysis Solution (Life Technologies) for $15 \mathrm{~min}$. RNA was extracted

322 from this lysate using the RNeasy Mini Kit (QIAGEN).

323 For the diel experiment, we used a phenol-chloroform-isoamyl extraction ${ }^{26}$ after confirming

324 good mRNA recovery from both diatom and bacterial samples. To determine the absolute number

325 of transcripts, two internal mRNA standards (size, 1,000 nt) were added to each sample before

326 extraction and the recovery of the standards was determined following Satinsky et al. ${ }^{23}$. After the

327 extraction, DNA was removed by the Turbo DNA-free Kit (Ambion), rRNA was depleted by Ribo-Zero

328 rRNA Removal Kit (Illumina), and mRNA was purified by RNA Clean \& Concentrator-5 (Zymo

329 Research) following the manufacturer's protocols. 
331 identified by blast+ (NCBI 2.7.1 and 2.8.1 for the direct light experiment and the diel experiment,

332 respectively) against an rRNA sequence database and removed. Remaining reads were mapped

333 to the R. pomeroyi genome and quantified using HTSeq ${ }^{61}$. Differentially expressed genes were

334 identified in pairwise comparisons of sampling times (diel experiment) or light levels (direct light

335 experiment) using MATLAB for absolute analysis, and DESeq $2^{62}$ for relative transcript analysis. One

336 of the replicate samples from the initial time point of the experiment was lost; otherwise, $n=3$ for

337 all analyses. The number of reads per library averaged $19.2 \times 10^{6}$ (range, $13.3-31.9 \times 10^{6}$ ) and the

338 percentage of rRNA contamination averaged 17.5\% (range, 4.1-38.8\%). Recovery of the two internal

339 standards was highly consistent (Pearson's $r=0.96 ; p \leq 0.001 ; n=26$ ), accounting for $2.2 \%$ of mRNA

340 reads recovered per library. All other statistical analyses were conducted using MATLAB. Fold-

341 change values and temporal pattern categories for all the genes are reported in Table S6.

342 Cell counts- A $0.5 \mathrm{~mL}$ aliquot of culture was fixed with glutaraldehyde (final concentration,

$3431 \%$ ) and kept at $-80^{\circ} \mathrm{C}$ until analysis. Samples were thawed, stained with SYBR Green I (Thermo

344 Fisher Scientific; final concentration, $5 \times 10^{-4}$ of commercial stock), and injected into a CytoFLEX flow

345 cytometer (Beckman Coulter). For phytoplankton counts, samples were analyzed without staining.

346 Data were analyzed using CytExpert (Beckman Coulter), and cell density was calculated based on a

347 separate run of a known concentration of bead standards (Beckman Coulter).

348 Model development - The extracellular release model was written in $\mathrm{R}$ version 3.6.1 with

349 three state variables, representing the phytoplankton endometabolome $(P)$, the exometabolome $(E)$,

350 and the bacterial endometabolome $(B)$. The time evolution of these pools was calculated at $0.1 \mathrm{~h}$

351 intervals using the following differential equations.

$$
\delta_{t} P=N X-T-R
$$




$$
\begin{aligned}
& \delta_{t} E=R-U \\
& \delta_{t} B=U-C
\end{aligned}
$$

353 irradiance oscillation around the peak in light intensity ${ }^{32} . T$ is the rate at which endometabolites are

354 allocated for biomass and energy generation by phytoplankton cells, calculated as a constant

355 fraction of $P$ at each interval. $R$ is release rate of endometabolites from the phytoplankton cell with

356 parameters for both diffusive and physiological balance mechanisms. $U$ represents bacterial uptake

357 from the exometabolome following Michaelis-Menten kinetics. $X$ is the bacterial response

358 mechanism that increases metabolite biosynthesis rate in the presence of bacteria by 1.5- or 2-fold.

359 C represents catabolism of the metabolite within the bacterial endometabolome, with a constant

360 fraction lost each interval. See Supplemental Methods for information on how variables $N, R, T, U$,

361 and $C$ were calculated.

To simulate experimental conditions, $B$ and $U$ were set to zero for $6 \mathrm{~d}$ of 'axenic growth'

363 followed by 'inoculation' with addition of $B$ and $U$ functions for the final $4 \mathrm{~d}$ of the modeled

364 experiment. Values for $P$ and $U$ from the final $2 \mathrm{~d}$ of model output were used to compare to

365 experimentally measured endometabolome and transcriptome data, respectively.

366 Experimental test of model predictions - T. pseudonana CCMP1335 was inoculated into L1

367 medium with $\mathrm{NaH}^{13} \mathrm{CO}_{3}$ labeling as described above. Triplicate samples were inoculated with three

368 heterotrophic bacteria (Ruegeria pomeroyi DSS-3, Stenotrophomonas sp. SKA-14, and Polaribacter

369 dokdonensis MED-152). Another set of triplicate samples was kept axenic (diatom only). The cultures

370 were maintained at $160 \mu \mathrm{mol}$ photons $\mathrm{m}^{-2} \mathrm{~s}^{-1}$ at $18^{\circ} \mathrm{C}$ in a $16: 8 \mathrm{~h}$ light:dark cycle. After $15 \mathrm{~d}$ (late

371 stationary phase) diatom cells were filtered from $700 \mathrm{~mL}$ of culture, frozen and processed for NMR

372 analysis as described above.

\section{Data Availability Statement}


375 accession number PRJNA649292 (sequencing data), and Metabolomics Workbench with Project ID

376 PR001019, dx.doi.org/10.21228/M80408 (metabolome data).

\section{Acknowledgements}

C. Smith and S. Sharma provided sequencing and bioinformatic assistance, J. Gluhska and C.

379 Panagos offered expertise on NMR analysis, M. Landa and B. Nowinski provided valuable comments

380 on experimental design, F. Ferrer-González and J. Schreier assisted with sampling, and the University

381 of Georgia Genomics and Bioinformatics Core (GGBC) provided sequencing services. This work was

382 supported by The Gordon and Betty Moore Foundation (5503), NSF (IOS-1656311), The Simons

383 Foundation (grant 542391 to MAM) within the Principles of Microbial Ecosystems (PriME)

384 Collaborative, JSPS (Research Fellowship for Young Scientists and Grant-in-Aid for JSPS Fellows to

$385 \mathrm{MU})$, and the Swedish Research Council (2018-06571 to MO).

\section{Author Contributions}

MU and MAM conceived of the study, MU and MO collected the data, MU, WS, MO, ASE, and MAM analyzed data, and MU and MAM wrote the paper with input from all authors. 


\section{References}

1 Williams, P. J. I. in Microbial Ecology of the Oceans (ed D. L. Kirchman) 153-200. (Wiley-Liss,, 2000).

2 Becker, K. W. et al. Daily changes in phytoplankton lipidomes reveal mechanisms of energy storage in the open ocean. Nature Comm 9 (2018).

3 Boysen, A. K. et al. Diel oscillations of particulate metabolites reflect synchronized microbial activity in the North Pacific Subtropical Gyre. bioRxiv, 2020.2005.2009.086173 (2020).

4 Durham, B. P. et al. Sulfonate-based networks between eukaryotic phytoplankton and heterotrophic bacteria in the surface ocean. Nat Microbiol 4, 1706-1715 (2019).

5 Aylward, F. O. et al. Microbial community transcriptional networks are conserved in three domains at ocean basin scales. Proc Nat Acad Sci 112, 5443-5448 (2015).

6 Gasol, J. M. et al. Diel variations in bacterial heterotrophic activity and growth in the northwestern Mediterranean Sea. Mar Ecol Prog Ser 164, 107-124 (1998).

7 Azam, F. et al. The ecological role of water-column microbes in the sea. Mar Ecol Prog Ser 10, 257-263 (1983).

8 Cole, J. J., Findlay, S. \& Pace, M. L. Bacterial production in fresh and saltwater ecosystems - a cross-system overview. Mar Ecol Prog Ser 43, 1-10 (1988).

9 Moran, M. A. et al. Deciphering ocean carbon in a changing world. Proc Nat Acad Sci 113, 3143-3151 (2016).

10 Nagata, T. in Microbial Ecology of the Oceans (ed D. L. Kirchman) 207-241 (John Wiley and Sons, Inc., 2008).

11 Kujawinski, E. B. The impact of microbial metabolism on marine dissolved organic matter. Ann Rev Mar Sci 3, 567-599 (2011).

12 Seymour, J. R., Amin, S. A., Raina, J. B. \& Stocker, R. Zooming in on the phycosphere: the ecological interface for phytoplankton-bacteria relationships. Nat Microbiol 2 (2017).

13 Thornton, D. C. O. Dissolved organic matter (DOM) release by phytoplankton in the contemporary and future ocean. Eur J Phycol 49, 20-46 (2014).

14 Bjornsen, P. K. Phytoplankton exudation of organic-matter - why do healthy cells do it. Limnol Oceanogr 33, 151-154 (1988).

15 Fogg, G. E. The ecological significance of extracellular products of phytoplankton photosynthesis. Bot Mar 26, 3-14 (1983).

16 Amin, S. A. et al. Interaction and signalling between a cosmopolitan phytoplankton and associated bacteria. Nature 522, 98-101 (2015).

17 Durham, B. P. et al. Recognition cascade and metabolite transfer in a marine bacteriaphytoplankton model system. Environ Microbiol 19, 3500-3513 (2017).

18 Armbrust, E. V. et al. The genome of the diatom Thalassiosira pseudonana: ecology, evolution, and metabolism. Science 306, 79-86 (2004).

19 Moran, M. A. et al. Genome sequence of Silicibacter pomeroyi reveals adaptations to the marine environment. Nature 432, 910-913 (2004). 
20 Uitz, J., Claustre, H., Gentili, B. \& Stramski, D. Phytoplankton class-specific primary production in the world's oceans: Seasonal and interannual variability from satellite observations. Global Biogeochem Cycles 24 (2010).

21 Buchan, A., LeCleir, G. R., Gulvik, C. A. \& Gonzalez, J. M. Master recyclers: features and functions of bacteria associated with phytoplankton blooms. Nat Rev Microbiol 12, 686698 (2014).

22 Luo, H. W. \& Moran, M. A. Evolutionary ecology of the marine Roseobacter clade. Microbiol Mol Biol R 78, 573-587 (2014).

23 Satinsky, B. M., Gifford, S. M., Crump, B. C. \& Moran, M. A. in Methods in Enzymology (ed E. F. DeLong) 237-250 (2013).

24 Moran, M. A. et al. Sizing up metatranscriptomics. Isme J 7, 237-243 (2013).

25 Durham, B. P. et al. Cryptic carbon and sulfur cycling between surface ocean plankton. Proc Nat Acad Sci 112, 453-457 (2015).

26 Landa, M., Burns, A. S., Roth, S. J. \& Moran, M. A. Bacterial transcriptome remodeling during sequential co-culture with a marine dinoflagellate and diatom. ISME J 11, 26772690 (2017).

27 Schwämmle, V. \& Jensen, O. N. VSClust: feature-based variance-sensitive clustering of omics data. Bioinformatics 34, 2965-2972 (2018).

28 Becker, S. et al. Laminarin is a major molecule in the marine carbon cycle. Proc Nat Acad Sci 117, 6599-6607 (2020).

29 Neidhardt, F., Ingraham, J. \& Schaechter, S. Physiology of the bacterial cell: a molecular approach. (Sinauer Associates Inc, 1990).

30 Wagner, G. P., Kin, K. \& Lynch, V. J. Measurement of mRNA abundance using RNA-seq data: RPKM measure is inconsistent among samples. Theory Biosci 131, 281-285 (2012).

31 Harding, L., Meeson, B., Prézelin, B. \& Sweeney, B. Diel periodicity of photosynthesis in marine phytoplankton. Mar Biol 61, 95-105 (1981).

32 Harding, L., Prezelin, B., Sweeney, B. \& Cox, J. Diel oscillations of the photosynthesisirradiance (PI) relationship in natural assemblages of phytoplankton. Mar Biol 67, 167178 (1982).

33 Behrenfeld, M. J., Halsey, K. H. \& Milligan, A. J. Evolved physiological responses of phytoplankton to their integrated growth environment. Phil Trans Royal Soc B: Biol Sci 363, 2687-2703 (2008).

34 Behrenfeld, M. J., Prasil, O., Babin, M. \& Bruyant, F. In search of a physiological basis for covariations in light-limited and light-saturated photosynthesis. J Phycol 40, 4-25 (2004).

35 Blough, N. V. \& Zepp, R. G. in Active oxygen in chemistry 280-333 (Springer, 1995).

36 Zafiriou, O. C., Joussot-Dubien, J., Zepp, R. G. \& Zika, R. G. Photochemistry of natural waters. Environ Sci Technol 18, 358A-371A (1984).

37 Ziegelhoffer, E. C. \& Donohue, T. J. Bacterial responses to photo-oxidative stress. Nat Rev Microbiol 7, 856-863 (2009).

38 Lubin, E. A., Henry, J. T., Fiebig, A., Crosson, S. \& Laub, M. T. Identification of the PhoB regulon and role of PhoU in the phosphate starvation response of Caulobacter crescentus. J Bacteriol 198, 187-200 (2016). 
39 Yang, C. et al. Genome-wide PhoB binding and gene expression profiles reveal the hierarchical gene regulatory network of phosphate starvation in Escherichia coli. Plos One 7 (2012).

40 Hsieh, Y. J. \& Wanner, B. L. Global regulation by the seven-component Pi signaling system. Curr Opin Microbiol 13, 198-203 (2010).

41 Kuipers, B., van Noort, G. J., Vosjan, J. \& Herndl, G. J. Diel periodicity of bacterioplankton in the euphotic zone of the subtropical Atlantic Ocean. Mar Ecol Prog Ser 201, 13-25 (2000).

42 Muratore, D. et al. Community-scale synchronization and temporal partitioning of gene expression, metabolism, and lipid biosynthesis in oligotrophic ocean surface waters. bioRxiv, 2020.2005.2015.098020 (2020).

43 Denger, K., Lehmann, S. \& Cook, A. M. Molecular genetics and biochemistry of $N$ acetyltaurine degradation by Cupriavidus necator H16. Microbiol-Sgm 157, 2983-2991 (2011).

44 Lidbury, I., Murrell, J. C. \& Chen, Y. Trimethylamine N-oxide metabolism by abundant marine heterotrophic bacteria. Proc Nat Acad Sci 111, 2710-2715 (2014).

45 Mou, X. Z., Sun, S. L., Rayapati, P. \& Moran, M. A. Genes for transport and metabolism of spermidine in Ruegeria pomeroyi DSS-3 and other marine bacteria Aquat Micro Ecol 59, 102-102 (2010).

46 Schulz, A. et al. Feeding on compatible solutes: A substrate-induced pathway for uptake and catabolism of ectoines and its genetic control by EnuR. Environ Microbiol 19, 926946 (2017).

47 Weinitschke, S., Sharma, P. I., Stingl, U., Cook, A. M. \& Smits, T. H. Gene clusters involved in isethionate degradation by terrestrial and marine bacteria. Appl Environ Microb 76, 618-621 (2010).

48 Nowinski, B. \& Moran, M. A. Identifying marine bacterial niche dimensions by an experimental invasion. submitted (2021).

49 Ottesen, E. A. et al. Pattern and synchrony of gene expression among sympatric marine microbial populations. P Natl Acad Sci USA 110, E488-E497 (2013).

50 Guillard, R. R. L. \& Hargraves, P. E. Stichochrysis immobilis is a diatom, not a chyrsophyte. Phycologia 32, 234-236 (1993).

51 Uchimiya, M., Tsuboi, Y., Ito, K., Date, Y. \& Kikuchi, J. Bacterial substrate transformation tracked by stable-isotope-guided NMR metabolomics: application in a natural aquatic microbial community. Metabolites 7, 52 (2017).

52 Lewis, I. A., Schommer, S. C. \& Markley, J. L. rNMR: open source software for identifying and quantifying metabolites in NMR spectra. Mag Res Chem 47, S123-S126 (2009).

53 Wishart, D. S. et al. HMDB 3.0-The Human Metabolome Database in 2013. Nuc Acids Res 41, D801-D807 (2013).

54 Ulrich, E. L. et al. BioMagResBank. Nuc Acids Res 36, D402-D408 (2008).

55 Toukach, P. V. \& Egorova, K. S. Carbohydrate structure database merged from bacterial, archaeal, plant and fungal parts. Nuclic Acids Res 44, D1229-D1236 (2016).

56 Landa, M. et al. Sulfur metabolites that facilitate oceanic phytoplankton-bacteria carbon flux. Isme J 13, 2536-2550 (2019). 
57 Boroujerdi, A. F. B. et al. Identification of isethionic acid and other small molecule metabolites of Fragilariopsis cylindrus with nuclear magnetic resonance. Anal Bioanal Chem 404, 777-784 (2012).

58 Walejko, J. M., Chelliah, A., Keller-Wood, M., Gregg, A. \& Edison, A. S. Global metabolomics of the placenta reveals distinct metabolic profiles between maternal and fetal placental tissues following delivery in non-labored women. Metabolites 8, 10 (2018).

59 Thaben, P. F. \& Westermark, P. O. Detecting rhythms in time series with RAIN. J Biological Rhythms 29, 391-400 (2014).

60 Welsh, J. CirHeatmap. (2020). <https://github.com/joadwe/cirheatmap $>$.

61 Anders, S., Pyl, P. T. \& Huber, W. HTSeq-a Python framework to work with highthroughput sequencing data. Bioinformatics 31, 166-169 (2015).

62 Love, M. I., Huber, W. \& Anders, S. Moderated estimation of fold change and dispersion for RNA-seq data with DESeq2. Genome Biol 15 (2014).

63 Schulz, A. et al. Feeding on compatible solutes: A substrate - induced pathway for uptake and catabolism of ectoines and its genetic control by EnuR. Environ Microbiol 19, 926-946 (2017).

64 Lidbury, I., Kimberley, G., Scanlan, D. J., Murrell, J. C. \& Chen, Y. Comparative genomics and mutagenesis analyses of choline metabolism in the marine Roseobacter clade. Environ Microbiol 17, 5048-5062 (2015).

65 Cunliffe, M. Purine catabolic pathway revealed by transcriptomics in the model marine bacterium Ruegeria pomeroyi DSS-3. FEMS Microbiol Ecol 92, fiv150 (2016). 
Table 1. Diatom endometabolites assigned with high confidence in the diel experiment. For detailed information for compound identification and confidence level information, see Table S1 and Fig. S1. Group assignments correspond to those in Figure 1. Statistical significance for temporal patterns is based on linear regression analysis for increasing or decreasing patterns, and RAIN for diel cycles. Temporal patterns: $M 1=$ increase, $M 2=$ decrease, M3 = diel with a peak at mid-afternoon, M4 = diel with a peak at noon. n.a., not applicable (membership value of $<0.5$, see text for the detail).

\begin{tabular}{|c|c|c|c|}
\hline $\begin{array}{l}\text { Compound category/ } \\
\text { Sub-category }\end{array}$ & Compound & Function & Group, temporal pattern \\
\hline Amine & Trimethylamine $\mathrm{N}$-oxide & & n.a. \\
\hline \multirow[t]{9}{*}{ Amino acid } & Ala & Amino acid metabolism & n.a. \\
\hline & $\operatorname{Arg}$ & Amino acid metabolism & n.a. \\
\hline & Asn & Amino acid metabolism & M-1 $(p<0.001)$ \\
\hline & Asp & Amino acid metabolism & $M-4(p<0.01)$ \\
\hline & Gln & Amino acid metabolism & M-4 $(p<0.001)$ \\
\hline & Glu & Amino acid metabolism & n.a. \\
\hline & Gly & Amino acid metabolism & $\mathrm{M}-1(p<0.01)$ \\
\hline & Lys & Amino acid metabolism & M-1 $(p<0.001)$ \\
\hline & Pro & $\begin{array}{l}\text { Amino acid } \\
\text { metabolism/osmoregulation }\end{array}$ & M-4 $(p<0.001)$ \\
\hline \multirow{3}{*}{$\begin{array}{l}\text { Amino acid/Branched- } \\
\text { chain }\end{array}$} & Val & Amino acid metabolism & n.a. \\
\hline & Ile & Amino acid metabolism & $\mathrm{M}-1(p<0.001)$ \\
\hline & Leu & Amino acid metabolism & $\mathrm{M}-1(p<0.001)$ \\
\hline \multirow[t]{3}{*}{ Amino acid derivative } & Glycine betaine & Osmoregulation & $M-1(p<0.05)$ \\
\hline & Dimethylglycine & & n.a. \\
\hline & Homarine & Osmoregulation & $M-1(p<0.05)$ \\
\hline Amino alcohol & Ethanolamine & Lipid metabolism & $\mathrm{M}-1(p<0.01)$ \\
\hline Choline & Choline & Lipid metabolism & n.a. \\
\hline Choline derivative & Phosphorylcholine & Lipid metabolism & M-1 $(p<0.001)$ \\
\hline Phosphocholine & Glycerophosphocholine & Lipid metabolism & n.a. \\
\hline Glycerol derivative & Glycerol 3-phosphate & Lipid metabolism & $M-1(p<0.01)$ \\
\hline \multirow[t]{3}{*}{ Nucleoside } & Adenosine & Nucleic acids/ATP constituent & n.a. \\
\hline & Guanosine & Nucleic acids/GTP constituent & $M-4$ \\
\hline & Uridine & & M-3 $(p<0.001)$ \\
\hline \multirow[t]{4}{*}{ Organic acid } & 3-Hydroxybutyrate & Carbon metabolism & $M-2(p<0.01)$ \\
\hline & Acetate & Carbon metabolism & $M-2(p<0.01)$ \\
\hline & 4-Hydroxyphenylacetate & & n.a. \\
\hline & $\begin{array}{l}\text { Dicarboxylic acids } \\
\text { (unidentified) }\end{array}$ & Carbon metabolism & $M-2(p<0.05)$ \\
\hline Sugar/Monosaccharide & Glucose & $\begin{array}{l}\text { Carbon/central energy } \\
\text { metabolism }\end{array}$ & $M-3(p<0.001)$ \\
\hline Sugar/Polysaccharide & $\beta(1,3)$-glucan & Carbon metabolism/storage & M-3 $(p<0.001)$ \\
\hline \multirow[t]{2}{*}{ Sulfur compound } & DHPS & Osmoregulation & M-1 $(p<0.001)$ \\
\hline & DMSP & Osmoregulation & $M-1(p<0.001)$ \\
\hline
\end{tabular}


Table 2. Bacterial noon/night ratios of transcripts cell ${ }^{-1}$ for genes indicative of metabolite consumption. Bold font indicates the compounds appearing in both the endometabolite and bacterial gene expression datasets. n.s., difference not statistically significant (adjusted $p>0.05$ ).

\begin{tabular}{|c|c|c|c|c|c|c|}
\hline & Compound & $\begin{array}{l}\text { Gene } \\
\text { locus tag }\end{array}$ & $\begin{array}{l}\text { Gene } \\
\text { name }\end{array}$ & Protein function & $\begin{array}{l}\text { Noon/Night } \\
\text { transcript ratio }\end{array}$ & $\begin{array}{l}\text { Refer- } \\
\text { ence }\end{array}$ \\
\hline \multirow[t]{4}{*}{ Amide } & Urea & SPO1707 & urtD & ABC transporter, ATP-binding protein & 43.0 & ${ }^{19}$ \\
\hline & & SPO1708 & urtC & $A B C$ transporter, permease & 37.7 & \\
\hline & & SPO1709 & urtB & $A B C$ transporter, permease & 34.6 & \\
\hline & & SPO1710 & urtA & $A B C$ transporter, substrate binding & 0.8 (n.s.) & \\
\hline \multirow[t]{3}{*}{ Amine } & TMAO & SPO1548 & $\operatorname{tmox}$ & $A B C$ transporter, periplasmic binding & 38.0 & 44 \\
\hline & & SPO1550 & tmoV & $A B C$ transporter, permease protein & 41.2 & \\
\hline & & SPO1549 & tmow & ABC transporter, ATP binding & 43.1 & \\
\hline Amine & TMA & SPO1551 & $\mathrm{tmm}$ & TMA monooxygenase & 42.6 & 19 \\
\hline $\begin{array}{l}\text { Amino acid } \\
\text { derivative }\end{array}$ & Betaine & SPO3186 & opuD & Glycine-betaine transporter & 1.6 (n.s.) & 19 \\
\hline \multirow[t]{4}{*}{ Amino Acid } & Leucine & SPO2793 & $i v D$ & isovaleryl-CoA dehydrogenase & 2.6 & \\
\hline & & SPO2789 & $m c c A$ & $\begin{array}{l}\text { methylcrotonyl-CoA carboxylase, } \\
\text { alpha subunit }\end{array}$ & 3.1 & \\
\hline & & SPO2790 & $m c c B$ & $\begin{array}{l}\text { methylcrotonyl-CoA carboxylase, } \\
\text { beta subunit }\end{array}$ & 3.4 & \\
\hline & & SPO0390 & & $\begin{array}{l}\text { glutamate/leucine/phenylalanine/val } \\
\text { ine dehydrogenase }\end{array}$ & 1.2 (n.s.) & \\
\hline \multirow[t]{3}{*}{$\begin{array}{l}\text { Amino acid } \\
\text { derivative }\end{array}$} & $\begin{array}{l}\text { Ectoine/ 5- } \\
\text { hydroxyectoine }\end{array}$ & SP01146 & uehB & $\begin{array}{l}\text { TRAP transporter, small integral } \\
\text { membrane protein }\end{array}$ & 48.4 & 63 \\
\hline & & SP01147 & uehA & $\begin{array}{l}\text { TRAP transporter, large integral } \\
\text { membrane protein }\end{array}$ & 29.7 & \\
\hline & & SP01145 & uehc & $\begin{array}{l}\text { TRAP transporter, periplasmic } \\
\text { binding }\end{array}$ & 36.7 & \\
\hline \multirow[t]{3}{*}{ Amino Acid } & Proline & SPO1031 & & hypothetical protein & 21.2 & \\
\hline & & SPO2441 & & $\begin{array}{l}\text { ABC transporter, periplasmic } \\
\text { betaine/proline-binding }\end{array}$ & 16.4 & \\
\hline & & SPOA0231 & & $\begin{array}{l}\text { ABC transporter, periplasmic } \\
\text { substrate-binding }\end{array}$ & 43.3 & \\
\hline Choline & Choline & SPO1087 & bet $T$ & Choline transporter & 0.9 (n.s.) & 64 \\
\hline \multirow[t]{4}{*}{$\begin{array}{l}\text { Glycerol } \\
\text { derivative }\end{array}$} & $\begin{array}{l}\text { SN-glycerol-3- } \\
\text { phosphate }\end{array}$ & SPO0238 & UgpE & $A B C$ transporter, permease & 4.3 & 19 \\
\hline & & SPO0239 & ugpA & $A B C$ transporter, permease & 3.3 & \\
\hline & & SPO0237 & upgC & ABC transporter, ATP-binding & 3.5 & \\
\hline & & SPO0240 & ugpB & $\begin{array}{l}\text { ABC transporter, periplasmic } \\
\text { substrate-binding protein }\end{array}$ & 1.3 (n.s.) & \\
\hline \multirow[t]{3}{*}{ Nuceloside } & Xanthine & SPO0654 & $x d h A$ & Xanthine dehydrogenase, A subunit & 33.4 & 65 \\
\hline & & SPO0653 & $x d h B$ & Xanthine dehydrogenase, B subunit & 33.0 & \\
\hline & & SP00652 & $x d h C$ & $\begin{array}{l}\text { Xanthine dehydrogenase accessory } \\
\text { factor }\end{array}$ & 25.8 & \\
\hline Nucleoside & Uridine & SPO2470 & iunH & $\begin{array}{l}\text { inosine-uridine preferring nucleoside } \\
\text { hydrolase }\end{array}$ & 9.9 & \\
\hline \multirow[t]{3}{*}{ Organic Acid } & Acetate & SP01813 & acs & acetyl-coenzyme A synthetase & 0.9 (n.s.) & \\
\hline & & SPO0325 & $p h b B$ & acetoacetyl-CoA reductase & 1.9 & \\
\hline & & SPO0326 & phbA & acetyl-CoA acetyltransferase & 1.1 (n.s.) & \\
\hline \multirow[t]{2}{*}{ Organic acid } & Glycolate & SPO3478 & $g / C D$ & glycolate oxidase, GlcD subunit & 18.6 & 19 \\
\hline & & SPO3479 & $g / c E$ & glycolate oxidase, GlcE subunit & 19.9 & \\
\hline
\end{tabular}




\begin{tabular}{|c|c|c|c|c|c|c|}
\hline & & SPO3480 & $g / c F$ & glycolate oxidase, iron-sulfur subunit & 21.6 & \\
\hline \multirow[t]{4}{*}{ Phosphonate } & Phosphonate & SPO0780 & phnc & ABC transporter, ATP-binding & 32.4 & \\
\hline & & SPO0781 & $p h n D$ & $\begin{array}{l}\text { ABC transporter, periplasmic } \\
\text { phosphonate-binding }\end{array}$ & 18.6 & \\
\hline & & SPO0782 & phnE-1 & $A B C$ transporter, permease & 38.3 & \\
\hline & & SPO0783 & phnE-2 & $A B C$ transporter, permease & 35.6 & \\
\hline \multirow[t]{4}{*}{ Polyamine } & Putrescine & SPO3469 & potF & $\begin{array}{l}\text { ABC transporter, periplasmic } \\
\text { putrescine-binding }\end{array}$ & 1.2 & 45 \\
\hline & & SPO3466 & potl & $A B C$ transporter, permease & 2.5 & \\
\hline & & SPO3467 & potH & $A B C$ transporter, permease & 2.6 & \\
\hline & & SPO3468 & potG & ABC transporter, ATP-binding & 2.1 & \\
\hline \multirow[t]{4}{*}{ Polyamine } & Spermidine & SPOA0381 & & $\begin{array}{l}\text { ABC transporter, periplasmic } \\
\text { substrate-binding protein }\end{array}$ & 22.7 & 45 \\
\hline & & SPOA0383 & & $A B C$ transporter, permease protein & 53.4 & \\
\hline & & SPOA0384 & & $A B C$ transporter, permease protein & 42.7 & \\
\hline & & SPOA0382 & & ABC transporter, ATP-binding protein & 29.2 & \\
\hline \multirow[t]{5}{*}{ Sugar } & Ribose & SPOA0253 & & $\begin{array}{l}\text { ABC transporter, periplasmic } \\
\text { substrate-binding }\end{array}$ & 30.9 & 26 \\
\hline & & SPOA0254 & $r b s c-1$ & $A B C$ transporter, permease & 54.9 & \\
\hline & & SPOA0256 & & $\begin{array}{l}\text { ABC transporter, periplasmic } \\
\text { substrate-binding protein }\end{array}$ & 21.4 & \\
\hline & & SPOA0257 & $r b s c-2$ & $A B C$ transporter, permease & 50.4 & \\
\hline & & SPOA0258 & $r b s A$ & ABC transporter, ATP-binding & 55.7 & \\
\hline \multirow[t]{3}{*}{ Sugar } & Glucose/Xylose & SPO0861 & $x y / F$ & $\begin{array}{l}\text { ABC transporter, periplasmic } \\
\text { substrate-binding }\end{array}$ & 2.7 (n.s.) & 26 \\
\hline & & SPO0862 & $x y / H$ & $A B C$ transporter, permease & 6.2 & \\
\hline & & SP00863 & $x y / G$ & $A B C$ transporter, ATP-binding & 4.2 & \\
\hline Sulfur compound & Choline-O-sulfate & SP01083 & betC & Choline sulfatase & 15.1 & ${ }^{64}$ \\
\hline \multirow[t]{4}{*}{ Sulfur compound } & Cysteate & SPO2658 & & $\begin{array}{l}\text { ABC transporter, periplasmic } \\
\text { substrate-binding }\end{array}$ & 22.4 & 56 \\
\hline & & SPO2659 & & $A B C$ transporter, permease & 38.3 & \\
\hline & & SPO2660 & & $A B C$ transporter, permease & 28.0 & \\
\hline & & SPO2661 & & ABC transporter, ATP-binding & 32.7 & \\
\hline \multirow[t]{3}{*}{ Sulfur compound } & $\begin{array}{l}\text { Dihydroxypropane- } \\
\text { sulfonate (DHPS) }\end{array}$ & SP00591 & hpsK & TRAP transporter & 13.0 & 25 \\
\hline & & SPO0592 & hpsL & TRAP transporter & 32.3 & \\
\hline & & SPO0593 & hpsM & TRAP transporter & 24.5 & \\
\hline \multirow[t]{5}{*}{ Sulfur compound } & $\begin{array}{l}\text { Dimethylsulfonio- } \\
\text { propionate (DMSP) }\end{array}$ & SP01913 & $d m d A$ & DMSP demethylase & 15.0 & 36 \\
\hline & & SPO0453 & $d d d W$ & DMSP lyase & 30.7 & \\
\hline & & SPO1703 & $d d d D$ & DMSP lyase & 41.3 & \\
\hline & & SPO2299 & $d d d P$ & DMSP lyase & 31.4 & \\
\hline & & SP01596 & $d d d Q$ & DMSP lyase & 19.2 & \\
\hline \multirow[t]{3}{*}{ Sulfur compound } & Isethionate & SPO2358 & iseK & TRAP transporter, periplasmic & 30.0 & 36 \\
\hline & & SPO2357 & isel & TRAP transporter, small permease & 13.2 & \\
\hline & & SPO2356 & iseM & TRAP transporter, DctM & 38.2 & \\
\hline \multirow[t]{3}{*}{ Sulfur compound } & $N$-acetyltaurine & SPO0660 & naaA & $\begin{array}{l}\text { ABC transporter, periplasmic } \\
\text { substrate-binding }\end{array}$ & 54.3 & 56 \\
\hline & & SPO0661 & $n a a B$ & $A B C$ transporter, permease & 32.3 & \\
\hline & & SPO0662 & $n a a B^{\prime}$ & $A B C$ transporter, permease & 42.7 & \\
\hline
\end{tabular}


bioRxiv preprint doi: https://doi.org/10.1101/2020.11.18.388827; this version posted November 20,2020 . The copyright holder for this preprint (which was not certified by peer review) is the author/funder, who has granted bioRxiv a license to display the preprint in perpetuity. It is made available under aCC-BY-ND 4.0 International license.

\begin{tabular}{lllllll} 
& SPO0663 & naaC & ABC transporter, ATP-binding & & 58.2 \\
Sulfur compound Taurine & SPO0664 & naaC' & ABC transporter, ATP-binding & 28.2 & 1.8 (n.s.) & s6 \\
& SPO0674 & tauA & ABC transporter, periplasmic & & \\
& & & substrate-binding & 3.7 \\
& SPO0675 & tauB & ABC transporter, ATP-binding & 3.1 \\
\hline
\end{tabular}


bioRxiv preprint doi: https://doi.org/10.1101/2020.11.18.388827; this version posted November 20, 2020. The copyright holder for this preprint (which was not certified by peer review) is the author/funder, who granted bioRxiv a license to disglay the preprint in perpetuity. It is made

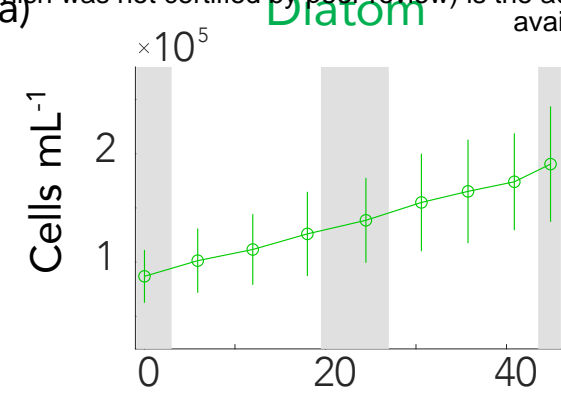

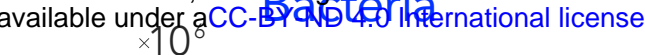

\section{Time $(h)$}

(b)
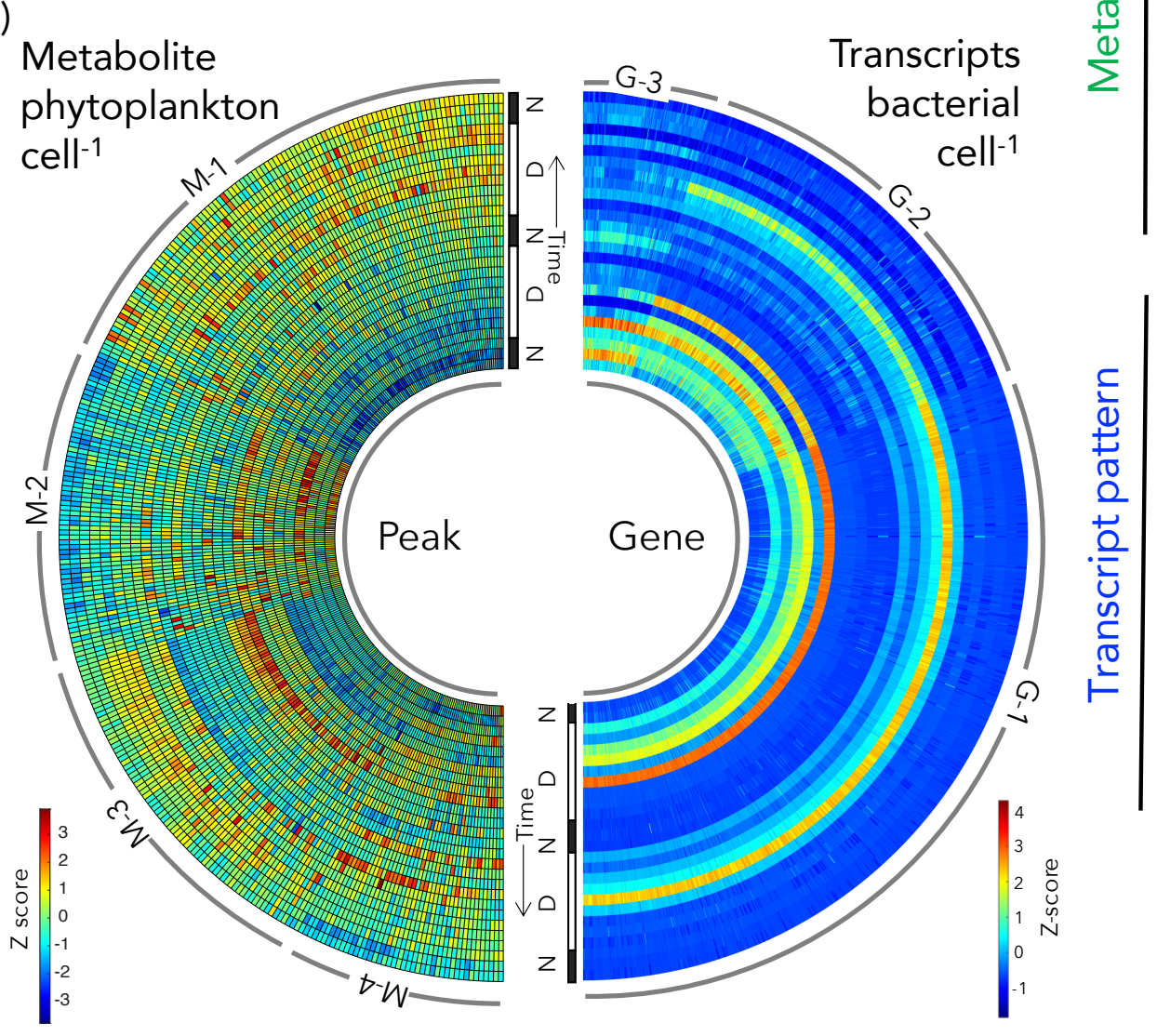

M-1

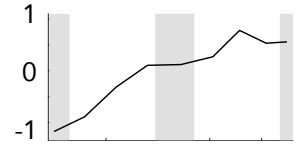

$\mathrm{M}-2$

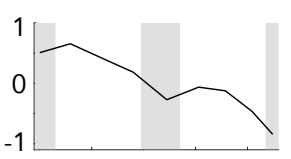

M-3

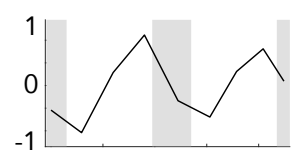

M-4

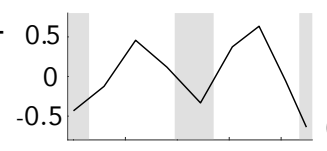

G-1

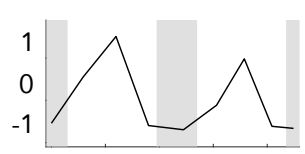

G-2

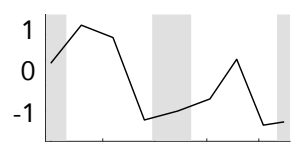

(756)

\section{G-3}

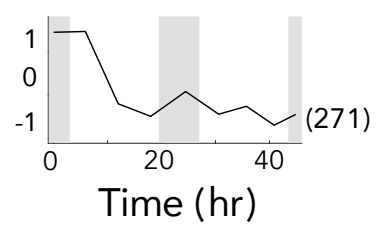

Figure 1. (a) Cell numbers of co-cultured diatoms and bacteria. (b) Temporal variations in metabolite concentration per diatom cell (left) and transcripts per bacterial cell (right) for genes differentially expressed between noon and night $(\geq 2$ fold-change and DESeq2 adjusted- $p \leq 0.05$ ). Values were converted to Z-scores and data from each of the three biological replicates are shown. (c) Temporal patterns identified for metabolites (M-1 through M-4) and gene transcription (G-1 through G-3). The number of metabolite peaks or genes in each cluster is given in parentheses. Grey shading in panels a and $\mathrm{c}$ indicates night. 

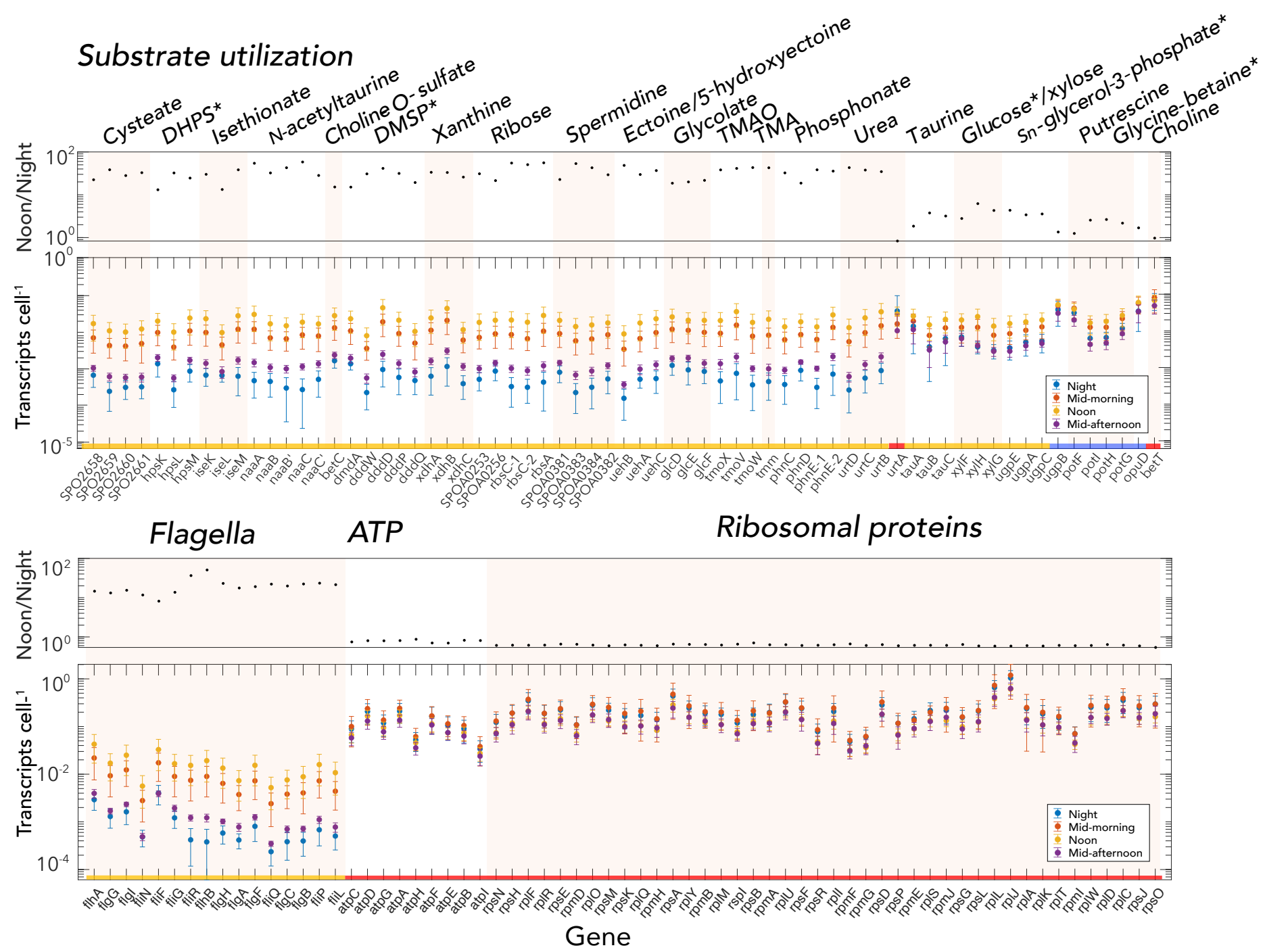

Figure 2. Expression levels of representative $R$. pomeroyi genes encoding transporters or diagnostic catabolic genes (top) and flagella, ATPases, and ribosomal proteins (bottom). For each panel, the top plot shows noon to night ratios (black circles), and the bottom plot shows average transcripts cell-1 at night, mid-morning, noon, and mid-afternoon. Error bars indicate standard deviations. Categories of transcription temporal patterns (G-1, gold; G-2, blue, G-3, red) are indicated along the x-axis. Asterisks indicate transporters whose target substrate matches an endometabolite identified with high confidence. 
bioRxiv preprint doi: https://doi.org/10.1101/2020.11.18.388827; this version posted November 20, 2020. The copyright holder for this preprint (which was not certified by peer review) is the author/funder, who has granted bioRxiv a license to display the preprint in perpetuity. It is made available under aCC-BY-ND 4.0 International license.

(a) Experiment (diel)

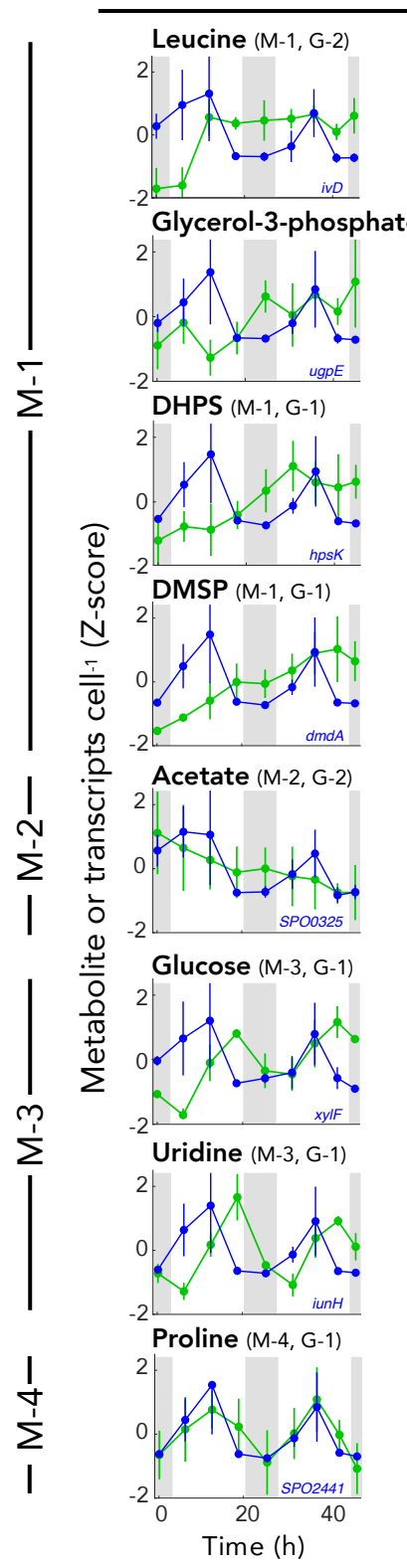

(b)

Model Output

Default model Response model
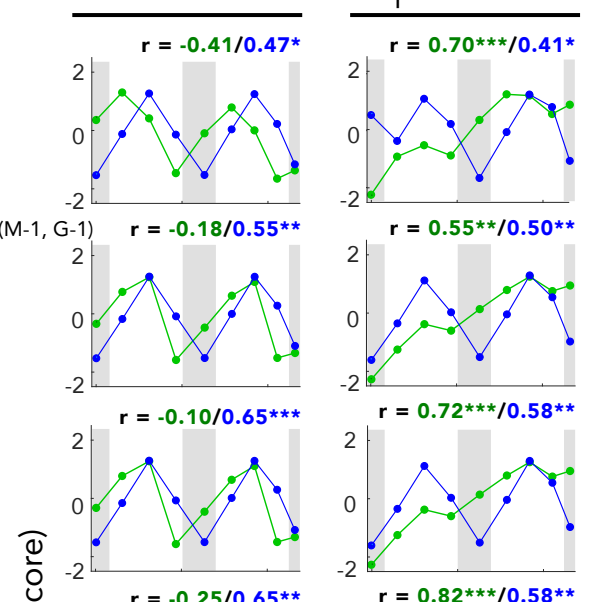

$r=0.55 * * / 0.50 * *$
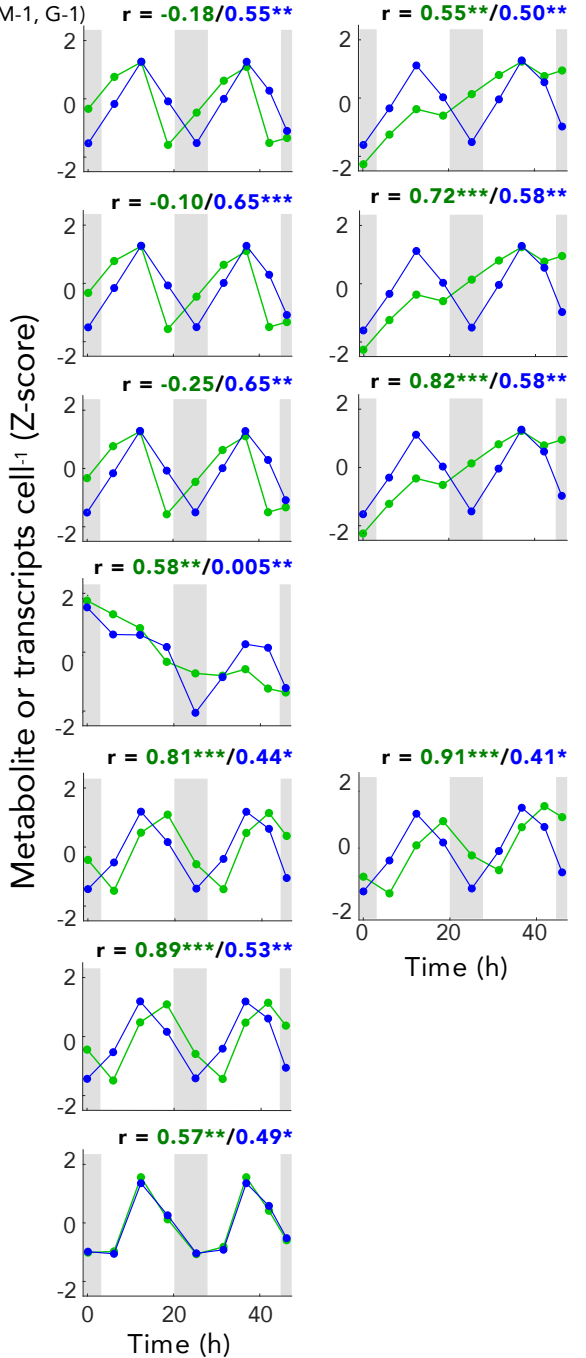

(c) Experiment $(15 d)$

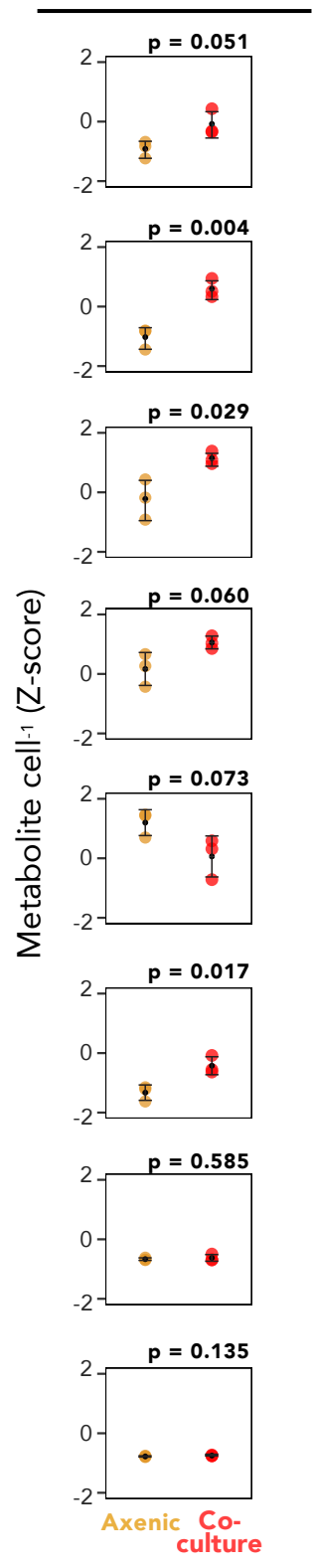

(d) Model Structure
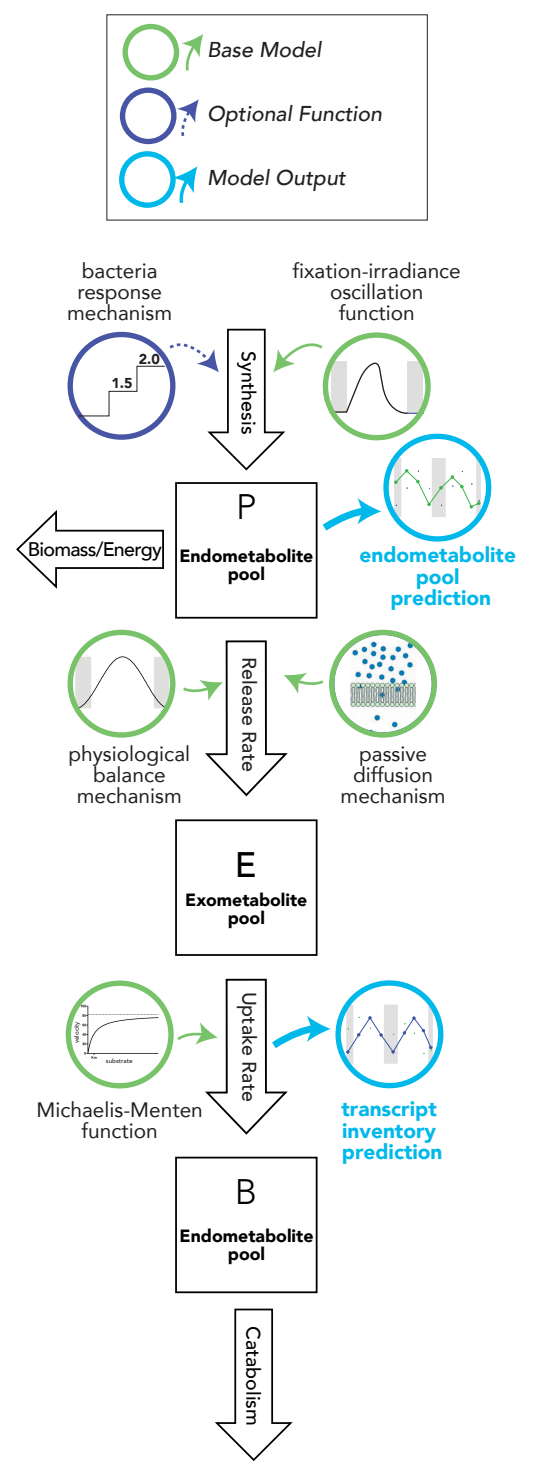

Figure 3. (a) Comparison of temporal patterns for diatom endometabolite concentration (green symbols) and bacterial transcript inventory for a representative gene encoding uptake or catabolism of the same compound (blue symbols); additional relevant genes are shown in Figure S8 (mean \pm standard deviation, $n=3$ except for the first night where $n=2)$. (b) Corresponding information from the model output for default (left) and response (right) models. Numbers above the plots indicate $r$ values for Pearson correlations between experimental and model data for metabolite concentrations (green font) and transcript inventories (blue font). ${ }^{*}, p \leq 0.05 ;{ }^{* *}, p \leq 0.01 ;{ }^{* \star *} p \leq 0.001$. (c) Comparison of diatom endometabolite concentrations in axenic culture versus bacterial co-culture (mean \pm standard deviation, $n=3$ ). Numbers above the plots indicate t-test $p$ values $(n=3)$. (d) Structure of simulation model. 


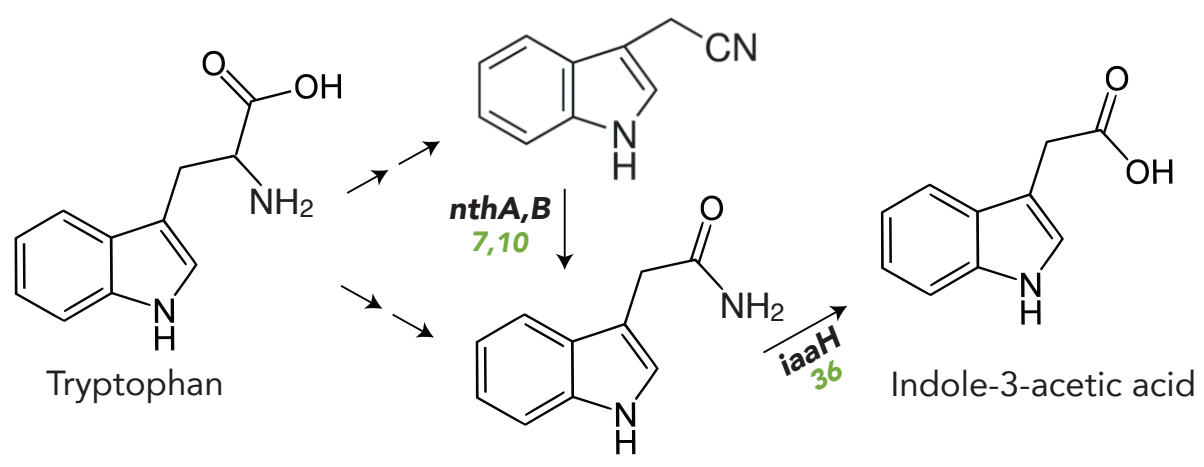

Indole-3-acetamide

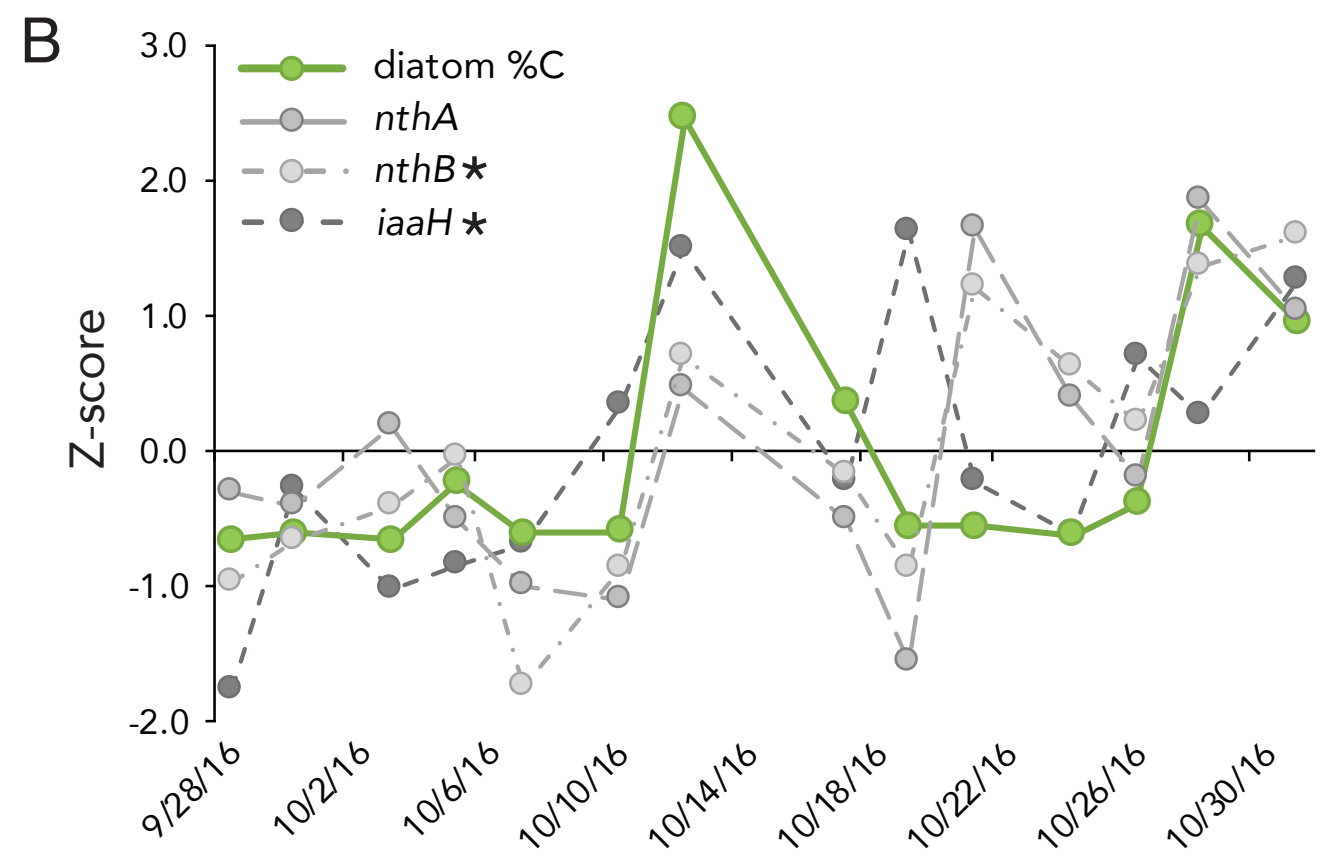

Figure 4. A) Indole-3-acetic acid (IAA) synthesis pathways in R. pomeroyi. nthA, $B$, nitrile hydratase; iaaH, IAM hydrolase; green text, noon/night per cell transcript inventories. B) Expression of $R$. pomeroyi IAA synthesis genes (gray symbols) following inoculation into natural phytoplankton bloom communities from Monterey Bay, CA, USA. Bacteria were added at 3-4 dintervals over a 1 mo period, with mRNA retrieved for transcriptome sequencing 90 min after inoculation ${ }^{48}$. The percent of phytoplankton carbon in the bloom community contributed by diatoms (green symbols) was calculated from microscopic cell counts and taxon-specific cell volumes. Data are Z-scores of mean values for three replicates. Asterisks indicate $R$. pomeroyi genes whose expression is positively correlated with diatom \% C (Pearson's $R \geq 0.54 ; p \leq 0.05$ ). 